\title{
Assessment of Geohazards and Preventative Countermeasures Using AHP Incorporated with GIS in Lanzhou, China
}

\author{
Hai-Min Lyu ${ }^{1,2}$, Jack Shuilong Shen ${ }^{1,2, *}$ and Arul Arulrajah ${ }^{3}$ \\ 1 State Key Laboratory of Ocean Engineering, School of Naval Architecture, Ocean, and Civil Engineering, \\ Shanghai Jiao Tong University, Shanghai 200240, China; lvhaimin@sjtu.edu.cn \\ 2 Collaborative Innovation Center for Advanced Ship and Deep-Sea Exploration (CISSE), \\ Department of Civil Engineering, Shanghai Jiao Tong University, Shanghai 200240, China \\ 3 Department of Civil and Construction Engineering, Swinburne University of Technology, \\ Hawthorn, VIC 3122, Australia; aarulrajah@swin.edu.au \\ * Correspondence: slshen@sjtu.edu.cn; Tel.: +86-21-3420-4301; Fax: +86-21-6419-1030
}

Received: 3 November 2017; Accepted: 21 January 2018; Published: 24 January 2018

\begin{abstract}
This research investigates geohazards and preventative countermeasures for Lanzhou City, China. To investigate the factors related to the development of geohazards in Lanzhou, the regional geological conditions around Lanzhou were investigated. The geomorphology of the region is comprised of a loess landform underlying quaternary loess deposits. A large number of faults induced by strong neotectonic movements are present in the area. Therefore, earthquakes frequently occur around Lanzhou. Earthquakes cause numerous rock falls and landslides, with landslide masses found scattered on the upper middle level of the area's mountains. When intense rainfall occurs, a lot of loose deposits are brought together along steep gullies, forming debris flows; hence, a disaster chain of earthquake-landslide-debris flow is formed. To evaluate the georisks around Lanzhou, the Analytic Hierarchy Process (AHP) was employed to assess geohazards. The spatial distribution of the evaluated georisk levels was mapped using a Geographic Information System (GIS). Based on the assessed results, about $55 \%$ of the urban area and $44 \%$ of Gaolan County have high or very high-risk levels. The ratio of relatively high disaster risk levels is up to $31 \%$ of the total area. To mitigate these geohazards, both strategic decision making and technical countermeasures should be implemented.
\end{abstract}

Keywords: geohazards; risk assessment; AHP and GIS; prevention countermeasures; Lanzhou City

\section{Introduction}

In recent years, many cities in China have been subjected to extreme weather hazards due to climatic changes [1-5]. Recent extreme weather events have included flooding hazards in Guangzhou City, Guangdong Province [1] and tornado hazards in Yancheng City, Jiangsu Province [2]. Large-scale geohazards in the northwestern region of China may also occur due to its special geographical location and semi-arid climatic conditions. In the northwestern region of China, geohazards (for example, earthquake-landslide-debris flow and flooding) frequently occur [6-12]. Figure 1 shows the geographical environment whereby uplift of the Tibetan Plateau induces strong neotectonic movement and the development of a large number of faults in the northwestern region. In the northwestern parts of the region, three mountain ranges (the Altay, Tianshan, and Kunlun Mountains) can be found. Two low-lying desert basins (the Junggar and Tarim Basins) are also located between these three mountain ranges. The Tibetan Plateau, the largest plateau in the world, is located at the southwestern region. The monsoon areas of eastern China, which contain plains and hills at lower elevations, are located in the southeastern region. As shown in Figure 1, Lanzhou City is located in a complex geological environment, surrounded by active faults, normal faults, and reverse faults. 


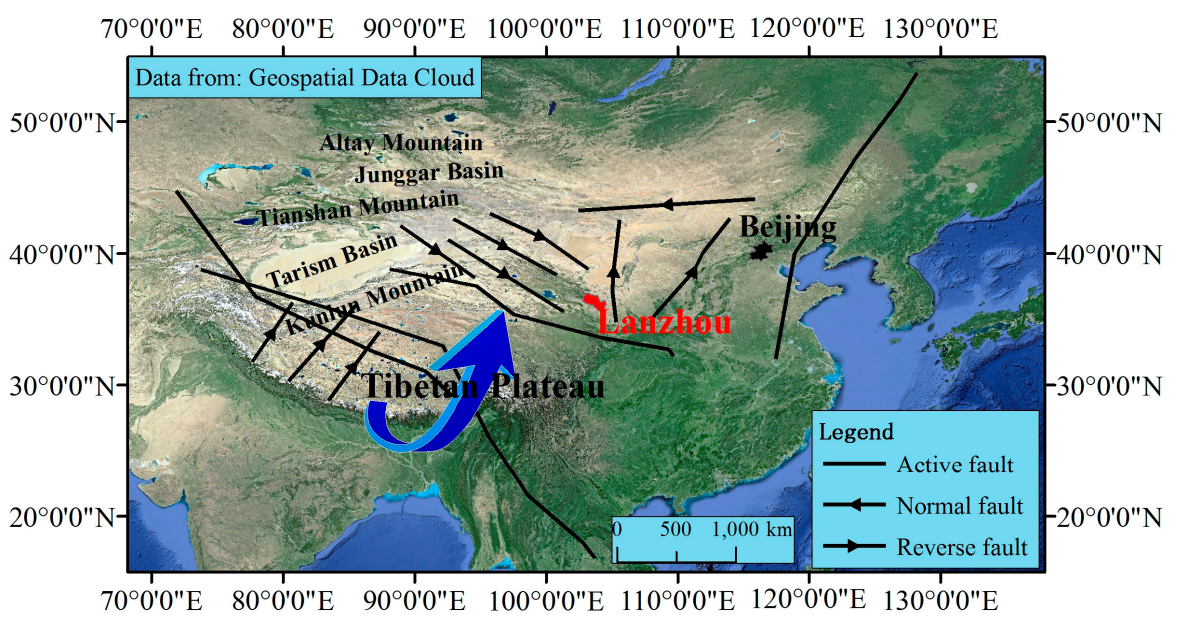

Figure 1. Geoenvironment of China and location of Lanzhou City.

With economic development, the urban scale of Lanzhou city is rapidly expanding. Numerous construction activities such as tunnel construction and excavation with ground water pumping have severely disturbed the natural geological environment [6]. To mitigate the influence caused by anthropic activities, Shen et al. (2013) [13] proposed a serious of ground improvement techniques for implementation in soft soil deposits [14-16]. Wu et al. $(2015,2016)[17,18]$ also proposed a new method for predicting geohazards in the process of tunnel construction. Geohazards caused by construction activities [19-21] and other anthropic activities, such as deforestation for agricultural use and artificial-irrigation-induced landslides, are increasing in frequency [22,23]. Anthropic activities have caused numerous geological disasters over the years [24,25]. According to statistics, since 1949, geological disasters have caused more than 670 deaths and economic losses of 776 million Chinese RMB (\$100 M USD) in Lanzhou [26].

Lanzhou, the capital city of Gansu Province, is located inland of the northwest region, which is the geometric center of China. Lanzhou City has frequently experienced strong tectonic movements and earthquakes $[27,28]$. The occurrence of an earthquake can induce landslides accompanied by debris flows [10,11]. Lanzhou also sits on loess deposits, which result in loess landslides under heavy rainfall, since loess is collapsible and loose in structure $[8,28]$. Intense short-duration rainfall is concentrated from July to September, and can easily induce debris flow and landslides because of the area's loose loess deposits. Moreover, mountains with rocky formations and geological faults are found in Lanzhou City. These mountains are in a weathered state and are covered by sedimentary rocks, also providing material for debris flows and landslides [26]. Geohazards readily occur in this region under the combined effects of complex geological formations, steep landforms, seasonal heavy rainfall, and anthropogenic activities. Therefore, it is urgent to perform a geohazard risk assessment for future sustainable development in and around Lanzhou.

There are three typically used methods of risk assessment: statistical analysis based on historical data [29-31]; multi-criteria indexing [32,33]; and geographic information system (GIS) and remote sensing technology [34,35]. Black and Burns (2002) [29] have presented an overview of changes in the estimation of Scottish river flood risks over time by reassessing flood records. Werritty (2013) [30] has applied trend analysis and current climatic change scenarios to identify issues in water resourcing. Li et al. (2014) [31] have argued that long-term historical flood materials are one of the most critical references for flood risk evaluation. Yet though assessment results can reflect the risks associated with a given study area, this approach requires a large amount of data and cannot accurately reflect spatial variation. Jiang et al. (2009) [32] and Kazakis (2015) [33] evaluated regional flood risk instead by establishing a multi-criteria indexing system. However, this method has a few deficits in determining subjective indices. GIS and remote sensing method have been adopted for flood risk assessment in urban areas; these two technologies also provide technological support for inundation 
risk evaluation [34,35]. Among these presented approaches, Analytic Hierarchy Process (AHP) is a useful tool for providing qualitative and quantitative assessment to decision makers. GIS is a powerful information integration system, which can be used to map the evaluated results of geohazards. Yi et al. (2010) [36] and Ayalew et al. (2005) [37] have developed a GIS-based framework for disaster prevention in Korea using the AHP method. Arisido et al. (2017) [38] and Zhang et al. (2009) [39] used Bayesian networks combined with GIS technology to assess flood risks. For our study, the AHP method combined with GIS technology was used to evaluate geohazard risks.

The objectives of this paper are to investigate potential geohazards in Lanzhou, to evaluate geohazard risk levels for the various districts in Lanzhou City, and to propose appropriate countermeasures to mitigate future catastrophic disasters.

\section{Backgrounds}

\subsection{Study Area}

Figure 2 shows the administrative map of Lanzhou, which includes five districts and three counties. The five districts constitute the urban area of Lanzhou: Chengguan, Qilihe, Xigu, Anning, and Honggu. The three counties are Yongdeng, Yuzhong, and Gaolan. The land area of Lanzhou is $13,085.6 \mathrm{~km}^{2}$ and contains a population of 3.6 million people, and the urban area is located within Lanzhou Basin, one of the largest basins in the middle of the Yellow River, located on the northeast edge of the uplifting Tibetan Plateau. The basin extends $40 \mathrm{~km}$ from northwest to southeast and is $10 \mathrm{~km}$ wide. It is divided into two parts, an eastern basin and a western basin, by a folding fault between Gaolan Mountain to the south and Baita Mountain to the north. In the rising Tibetan Plateau, river terraces are usually regarded as topographic evidence of tectonic movement.

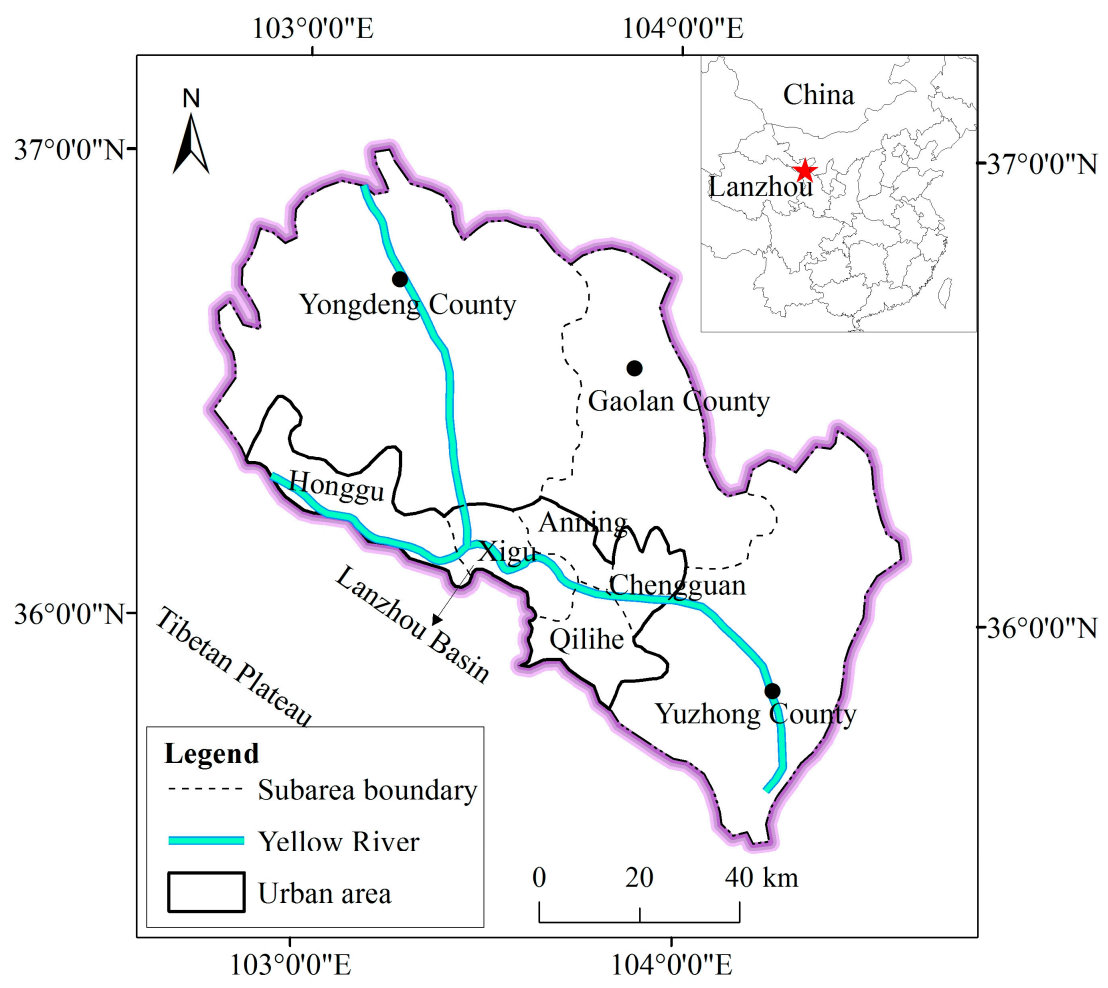

Figure 2. Map of the administrative region of Lanzhou.

\subsection{Topography}

Topography has a critical influence on the development of geohazards. For example, the distribution of flooding hazards is significantly affected by variations in spatial topography [40]. 
Flat areas in particular are prone to flood. River networks play an important role in the reduction of floodwaters during flood events. The average altitude of China's northwestern region ranges from 2000 to 3000 m. The Yellow River, which starts on the Tibetan Plateau in Qinghai Province, passes through the provinces of Qinghai, Sichuan, Gansu, Ningxia, Inner Mongolia, Shanxi, and Henan.

Figure 3 illustrates the altitude and distribution of the river system in Lanzhou. The altitude of Lanzhou ranges from 3796 to $1423 \mathrm{~m}$ with an average of approximately $2500 \mathrm{~m}$. The Lanzhou urban area is located at a lower altitude, while Yongdeng County and Yuzhong County are located at higher altitudes. Furthermore, the urban area is located in the centre of Lanzhou, which tends to collect rainwater from the northern and southern areas, as can be seen in Figure 3; hence the Lanzhou urban area is prone to flooding during heavy rainstorm events. Since flooding always induces landslides accompanied with debris flows, the Lanzhou urban area is highly vulnerable to geohazards.

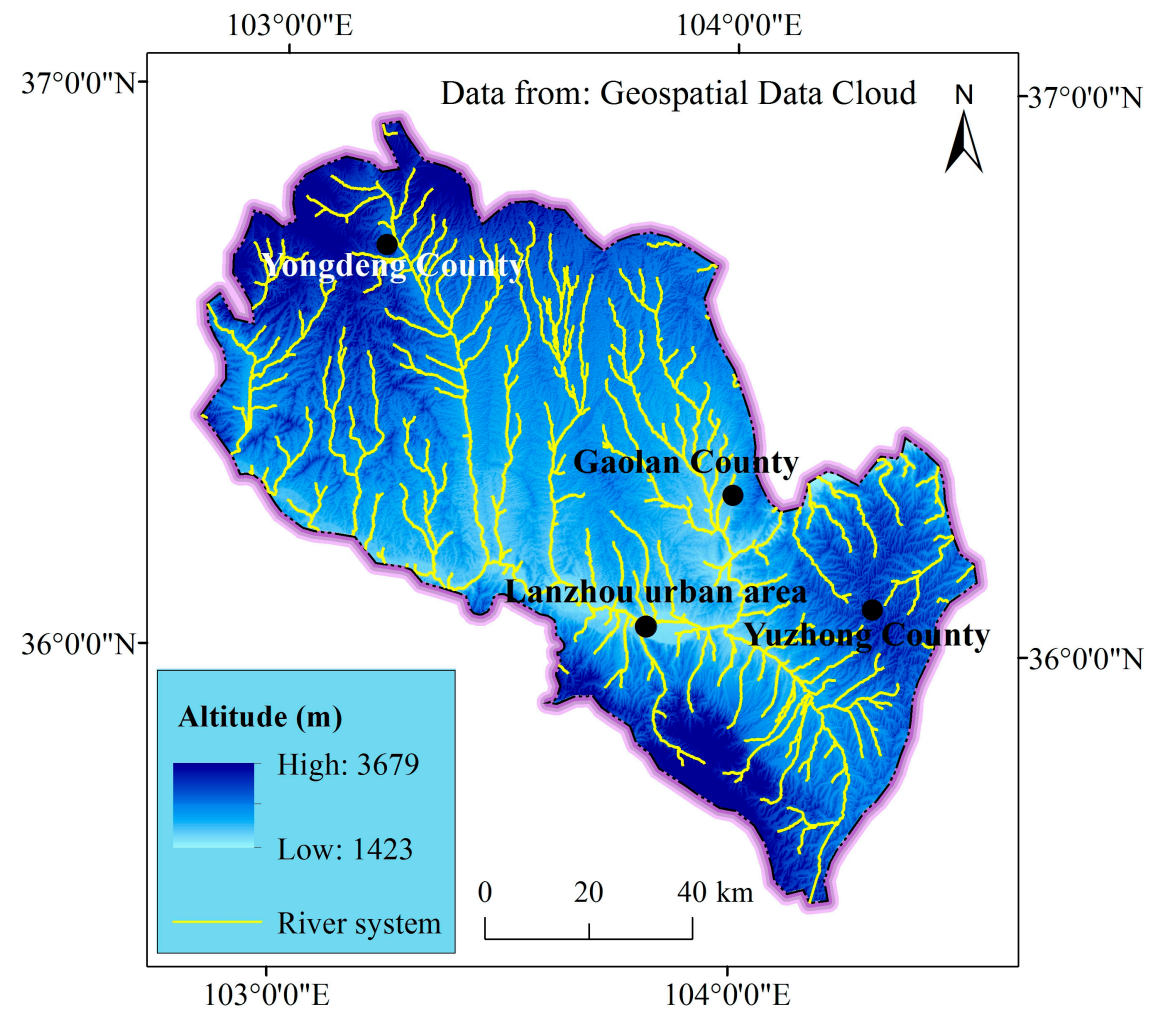

Figure 3. Distribution of altitude and river systems in Lanzhou.

\subsection{Geology}

\subsubsection{Loess Landforms}

Longzhong Plain, known as the Chinese Loess Plateau, is covered by deep loess deposits at the northwestern side. These loess deposits are predominantly quaternary deposits, and can be divided into the Wuchen Loess, Lishi Loess, and Malan Loess deposits. Its loess landforms make the terrain of Lanzhou unique. Figure 4 shows the distribution of loess landforms across northwestern China [41]. As shown, these loess landforms are widely distributed, occurring in Lanzhou City, Gansu Province, Shanxi Province, Xining Province, and Yinchuan City. According to existing statistical data, quaternary loess covers $66 \%$ of the land surface of Lanzhou, with the thickness of loess deposits ranging from 100 to $150 \mathrm{~m}$ [27]. The loess landforms have many vertical joint fissures, which are always present in the loess plateau [42]. The characteristics of these sediments provide source material for the development of geohazards. 


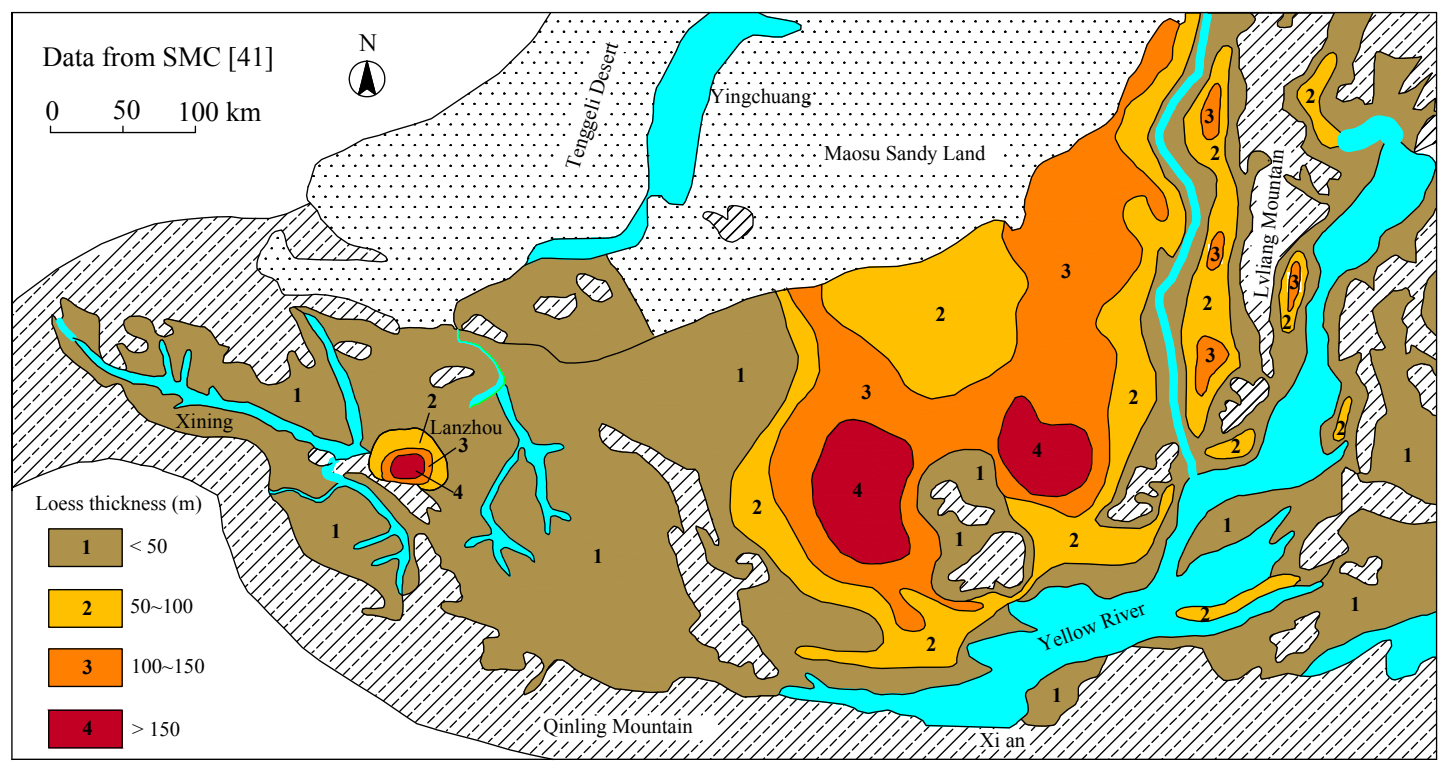

Figure 4. Distribution of loess landform across southwestern China.

\subsubsection{Geological Structures}

Topographically, the Lanzhou urban area is a vulnerable place. Many geologic faults have developed in northwestern China, forming its special geographical environment. Figure 5 shows the distribution of faults around Lanzhou City. Because the Yellow River passes through the city, the area comprises four faulted-erosion basins. The Yellow River lies in the geometric centre of the rhomboidal western basin, which is demarcated by the Leitanhe Fault to the east, the Xinglong Fault to the south, the Shengou Fault to the west and the Jinchengguan Fault to the north [43]. Cretaceous and tertiary strata are deposited between Gaolan Mountain and Baita Mountain. Tectonic movements play an important role in the height of the uplifted strata, leading to a $2151 \mathrm{~m}$ height difference between Xinglong Mountain and the river valley region. Neotectonic movements are extremely strong in the Lanzhou urban area. Complex geological conditions and active faults around Lanzhou result in frequent earthquakes [44].

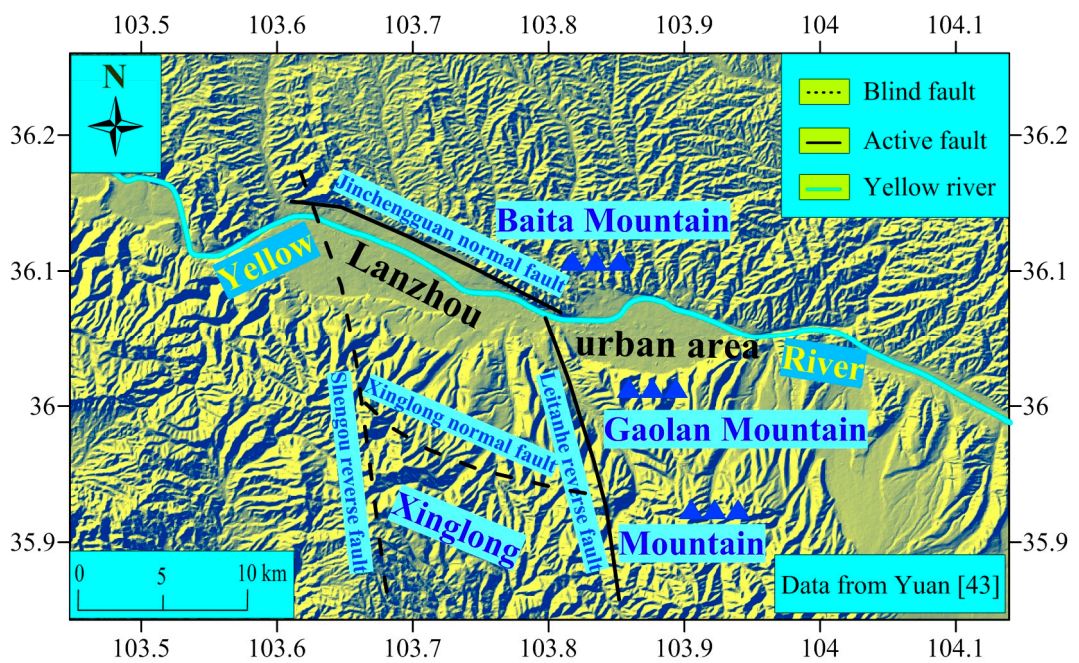

Figure 5. Distribution of faults around Lanzhou urban area. 


\subsection{Hydrology}

Lanzhou has a semi-arid climate and the loess is sensitive to climatic changes. Variations in altitude create temperature and climatic extremes. Figure 6 shows the hydrologic characteristics of Lanzhou City. As is shown, recorded data indicate significant temperature differences between the highest temperature $\left(22.1^{\circ} \mathrm{C}\right)$ and the lowest temperature $\left(-6.1^{\circ} \mathrm{C}\right)$. The rainfall in Lanzhou is relatively low, averaging $35.4 \mathrm{~mm}$, and the heaviest rainfall is always accompanied by the greatest average temperature. Statistics show that almost $70 \%$ of rainfall is comprised of high-intensity and short-duration rainstorm events [26]. Continuous rainfalls of more than seven consecutive days occur from July to September [26].

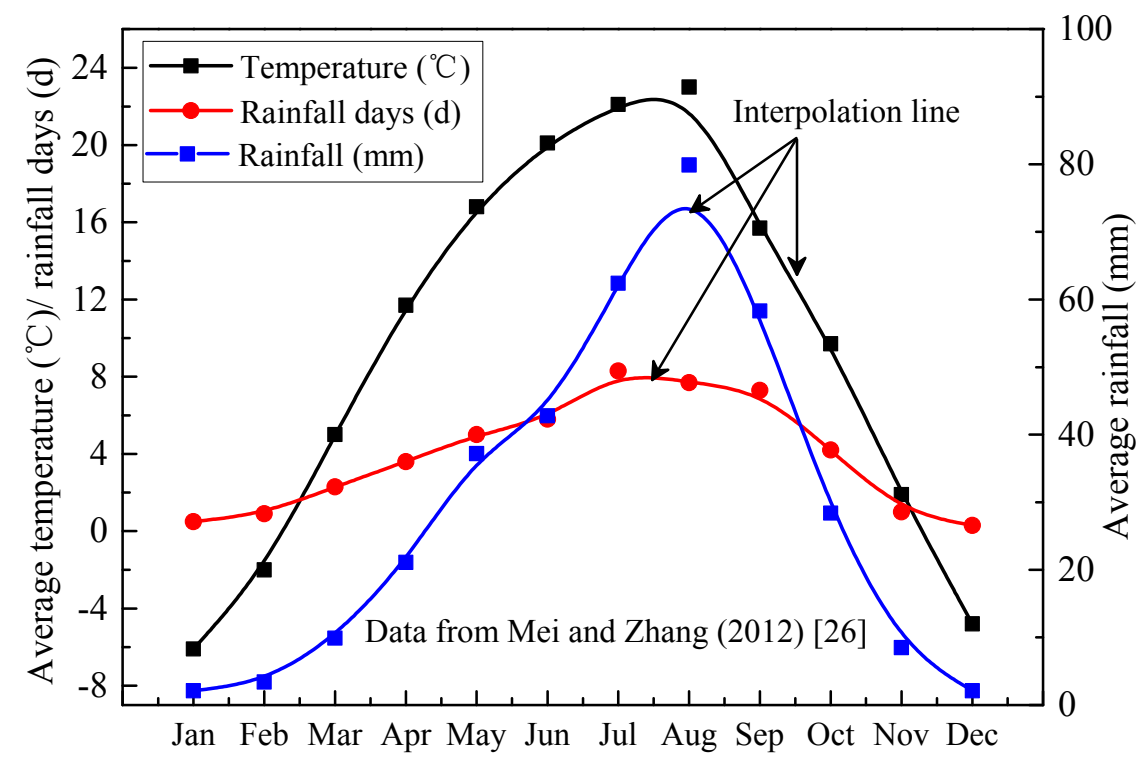

Figure 6. Hydrology characteristics of Lanzhou City.

Rainfall plays an important role in the development of geohazards. Soils generally have high shear stress when unsaturated, but relatively low values when fully saturated [42,45]. Rainfall infiltration reduces soil shear strength, leading to the occurrence of geohazards [46,47]. The concentrated rainfall from July to September results in numerous geohazards during those months.

\section{Methodology}

Risk assessment is a quantitative or qualitative measure of risk related to a well-defined situation and an acceptable threat. Quantitative risk assessment needs to calculate two components of risk: the magnitude of potential loss and the probability of loss occurrence. An acceptable risk is one in which the cost or difficulty of implementing an effective countermeasure exceeds the expectation of loss.

\subsection{Assessment Method}

According to the literature [48,49], "disaster risk is a function of three components: hazard, exposure and vulnerability. Vulnerability is the reaction of the assets when exposed to the spatially variable forces produced by a hazard event. Vulnerability reveals the situation in future". This study does not consider the reaction after disaster; for our purposes, disaster risk is composed of hazard and exposure.

A hazard is an agent which may cause harm to a vulnerable target. Often the terms hazard and risk are used interchangeably. However, in the field of risk assessment, these two terms are different. A hazard is an agent that can induce harm or damage to humans, property, or the environment. Risk is 
the probability that exposure to a hazard will result in a negative consequence. Thus, a hazard poses no risk if there is no exposure to that hazard [49]. Therefore, in this study, geohazard risk is considered as the combination of hazard and exposure [50,51]. The disaster risk model used can be described by the following equation:

$$
\text { Geohazards risk }=\text { Hazard } \otimes \text { Exposure }
$$

where $\otimes$ is not a mathematical operation symbol. This equation is used only to express the definition of risk.

Geohazard risk means that the development of disaster, which is associated with the interactions between hazard and exposure, is uncertain. Thus, the geohazard risk assessment model can be expressed by Equation (2):

$$
R=f\left(S_{k}\right)=f(H, E)
$$

where $R$ is risk and $k$ is the index classification number. When $k=1$, it is the hazard index; and when $k=2$, it is the vulnerability index. $S_{k}$ refers to each factor in the assessment model, and can be calculated using Equation (3):

$$
S_{k}=\sum_{i=1}^{n} f_{k, i} F_{k, i}
$$

where $F_{k, i}$ is the normalized value of index $i$ of classification $k, f_{k, i}$ is the weight of index $i$ of classification $k$, and $\sum_{i=1}^{n} f_{k, i}=1, f_{k, i}>0$.

Therefore, the assessment model can be redefined as Equation (4):

$$
R=\sum_{i=1}^{n} h_{i} H_{i} \otimes \sum_{k=1}^{n} e_{k} E_{k}
$$

where $R$ is risk, $H_{i}$, and $E_{k}$ are the hazard factor and exposure factor, and $h_{i}$, and $e_{k}$ are the weight coefficients of each factor.

To evaluate the geohazard risks of Lanzhou City, the analytic hierarchy process (AHP) was incorporated into the GIS. AHP is a useful method of evaluating both qualitative and quantitative risk [52-54]. The assessment procedure was implemented to build a risk assessment index system based on the factors affecting geohazards; to determine the weight of each assessment factor using AHP; to normalize each factor in the assessment system; to map the distribution of risk level of each assessment index; and to visualize the spatial distribution of geohazard risks in the regional scale using GIS.

\subsection{AHP Assessment Structure}

In this study, the risk of geohazards was evaluated by AHP in which the effects from both hazard and exposure were expressed by indices with different weights. Figure 7 shows the assessment structure for geohazard risk. This structure includes three parts: object layer, index layer, and factor layer. In the assessment structure, the object layer is geohazards risk (U). The index layer includes hazard index $\left(\mathrm{U}_{1}\right)$ and exposure index $\left(\mathrm{U}_{2}\right)$ the hazard index includes five factor layers-annual average rainfall $\left(\mathrm{U}_{11}\right)$, annual average rainy day $\left(\mathrm{U}_{12}\right)$, geological environment $\left(\mathrm{U}_{13}\right)$, earthquake magnitude $\left(U_{14}\right)$, and historical disaster $\left(U_{15}\right)$ - while the exposure index includes four factor layers: topographical slope $\left(U_{21}\right)$, topographical elevation $\left(U_{22}\right)$, river density $\left(U_{23}\right)$, and river proximity $\left(U_{24}\right)$. 


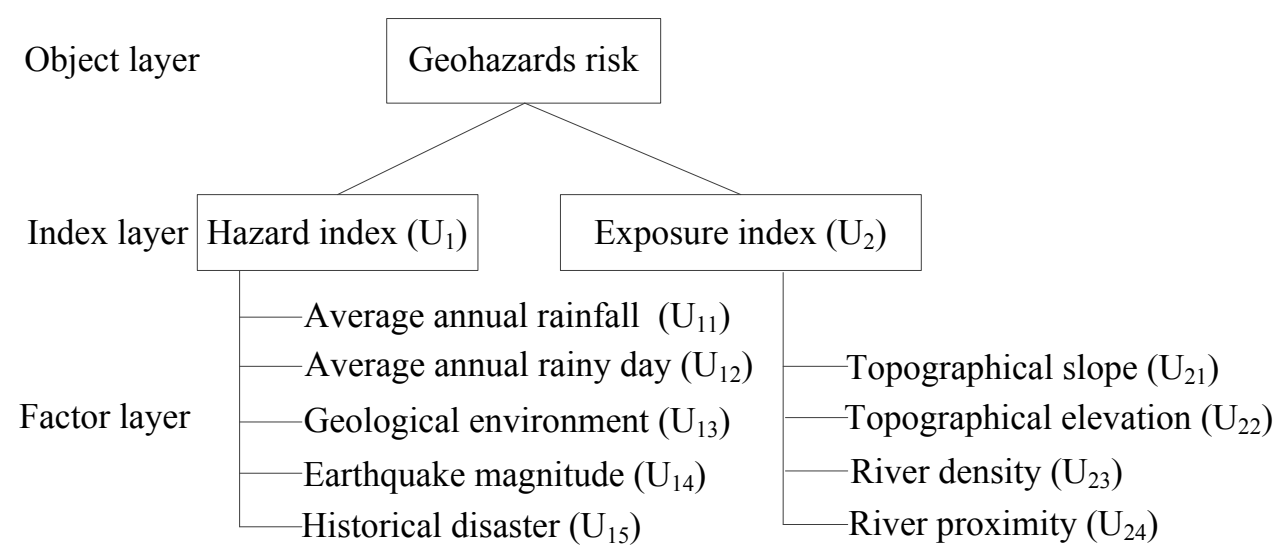

Figure 7. Analytic Hierarchy Process (AHP) structure for assessment of geohazards risk.

\subsection{Weight Calculation by AHP}

Based on the assessment structure, the judgment matrix of each assessment factor can be expressed by Equation (5):

$$
B_{p}=\left(b_{i j}\right)=\left(\begin{array}{cccc}
b_{11} & b_{12} & \cdots & b_{1 m} \\
b_{21} & b_{22} & \cdots & b_{2 m} \\
\vdots & \vdots & \ddots & \vdots \\
b_{m 1} & b_{m 2} & \cdots & b_{m m}
\end{array}\right)_{p}
$$

where $B_{p}$ is the judgment matrix and $b_{i j}$ is the element of judgment matrix, which represents the relative importance of factor $b_{i}$ to factor $b_{j}$. When $b_{i}$ is significantly more important than $b_{j}, b_{i j}$ is set to 9 and $b_{j i}$ is set to $1 / 9$.

Then, the weight coefficient of each factor can be calculated by Equation (6):

$$
w_{i}=\frac{M_{i}}{\sum_{i=1}^{n} M_{i}}
$$

where $M_{i}=\sqrt[n]{\prod_{j=1}^{n} b_{i j}} ; b_{i j}$ is the relative value of $i$ factor to $j$ factor, which ranges from 1 to 9 and their reciprocals.

The consistency of judgment matrix can be validated by the value of consistency ratio (CR). It can be calculated by the following equation:

$$
C R=\frac{C I}{R I}
$$

where $C I=\left(\lambda_{\max }-n\right) /(n-1)$ and $\lambda_{\max }$ is the largest eigenvalue of the judgment matrix, which can be calculated based on Equation (8). $R I$ is the average random consistency index.

$$
\lambda_{\max }=\sum_{i=1}^{n} \frac{\sum_{j=1}^{n} a_{i j} w_{i}}{n w_{i}}
$$

If the value of $C R$ is less than 0.1 , then the matrix is reasonable, and should be reestablished.

Using AHP incorporated with GIS technology, the level of geohazards risk can be evaluated and the spatial distribution of geohazards risk can be mapped. 


\subsection{Normalization}

To compare differences between each factor, all factors should be normalized before overlay analysis. After normalization, the value of each factor ranged from 0 to 1 . For all assessment factors, risk will increase with greater topographic elevation and slope, and decrease with less river density. Thus, the assessment factors can be divided into two types: negative factors and positive factors. Positive factor and negative factor are normalized using Equations (9) and (10), respectively.

$$
\begin{aligned}
& \stackrel{\vee}{i}_{m}=\frac{i_{m}-i_{\min }}{i_{\max }-i_{\min }} \\
& \hat{i}_{m}=\frac{i_{\max }-i_{m}}{i_{\max }-i_{\min }}
\end{aligned}
$$

where $\stackrel{\vee}{i}_{m}$ and $\hat{i}_{m}$ are the normalized values of the assessment factors, $i_{m}$ is the original value, $i_{\text {max }}$ is the maximum value of the factor, and $i_{\min }$ is the minimum value. To facilitate the accuracy of the assessment results, all factors were based on a resolution of $30 \mathrm{~m}$.

\subsection{Extraction of Topography}

Topography has critical effects in the development and redistribution of geohazards. Elevation and slope are widely used to reflect topographic characteristics. Natural hazards (for example, landslides accompanied with debris flows and floods) can cause considerably more catastrophic damage in flat regions than in steep regions. An area with a flat slope has a high risk of disaster [50,51]. Moreover, the river system also has an important role in inducing disasters, for example floods. The occurrence of flooding is related to the distribution of the drainage system. The river system not only can assist in draining rainwater but also can induce flooding [50,51]. Figure 8a-d show the area's topographic characteristics. For this paper, topographic elevation and slope were extracted from a digital elevation model (DEM) with a $30 \mathrm{~m}$ resolution in GIS environment. The original DEM data can be obtained from the geospatial data cloud (http:/ / www.gscloud.cn/). River density refers to the length of the water channel per unit and was derived using a source radius of $1 \mathrm{~km}$. River proximity refers to the distance to the closest river channels. The critical levels of proximity were set at $200 \mathrm{~m}, 400 \mathrm{~m}, 600 \mathrm{~m}, 800 \mathrm{~m}$, and $1000 \mathrm{~m}$, respectively.
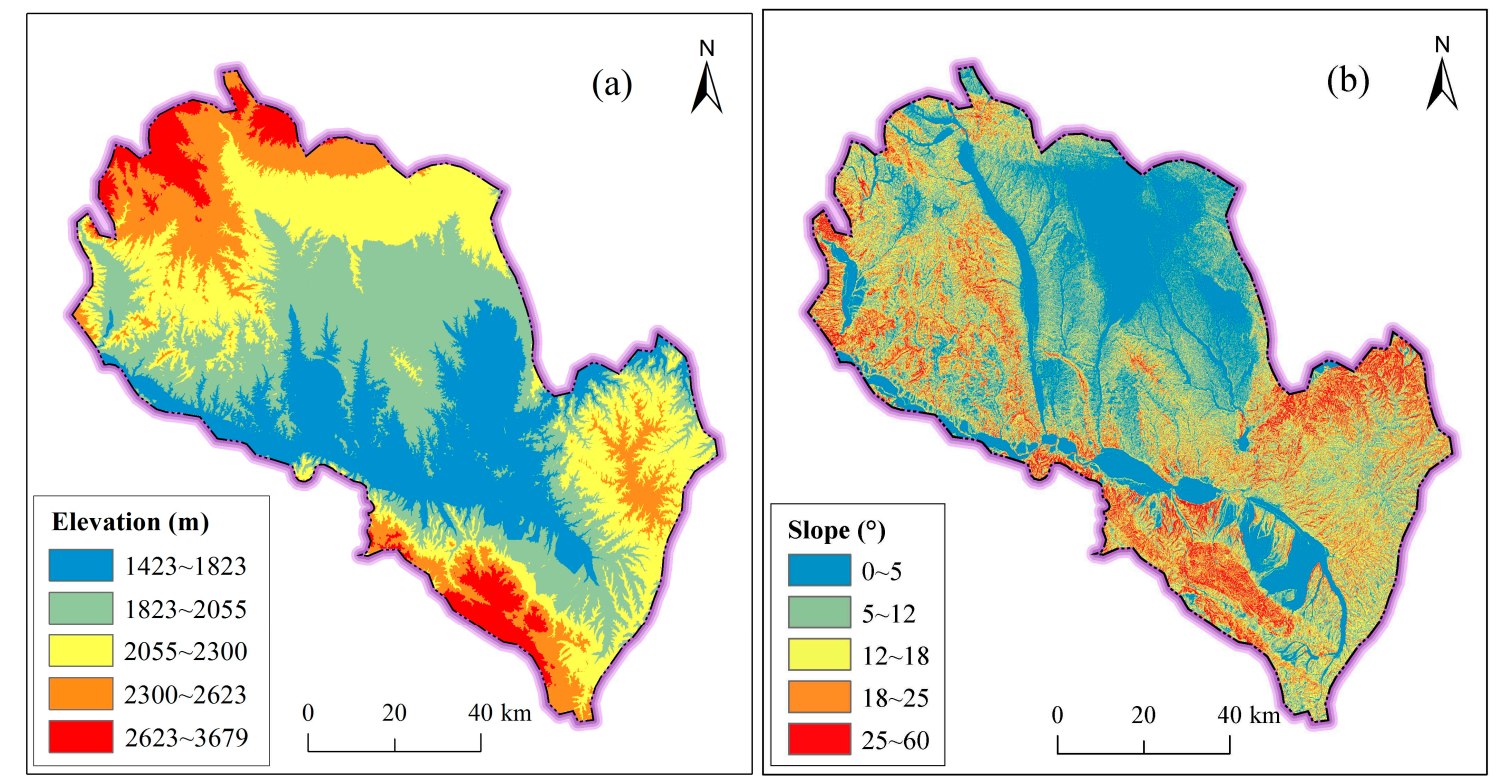

Figure 8. Cont. 


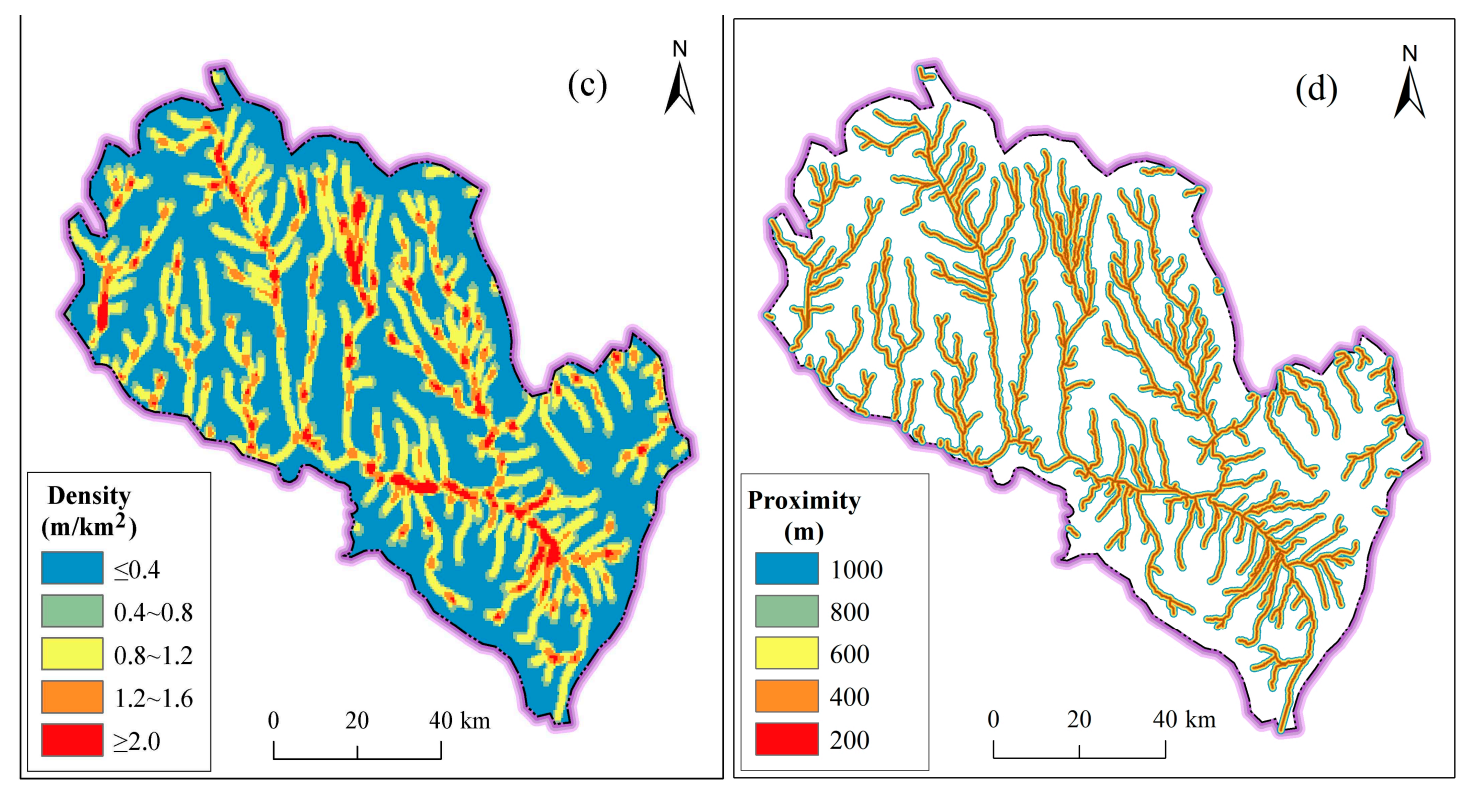

Figure 8. Topographical characteristics: (a) elevation; (b) slope; (c) river density; (d) river proximity.

\subsection{Investigation of Geohazards}

Geohazards including debris flow, landslide, earthquake, and flooding are widely distributed and frequent in Lanzhou. Long-term historical geohazards are one of the most critical references for flood risk evaluation $[29,30]$. Figure $9 \mathrm{a}, \mathrm{b}$ show the historical distribution of earthquakes and other geohazards in Lanzhou. Comparing Figure 9a to Figure 5 shows that the distribution of earthquake epicenters corresponds to the distribution of faults. As shown in Figure 9b, landslides are often accompanied by debris flows. The predominant geohazards in the region are debris flow; landslides accompanied by debris flow; intense rainstorms which induce flooding; earthquake; and flooding, which has significant effects on the development of debris flow and landslides.
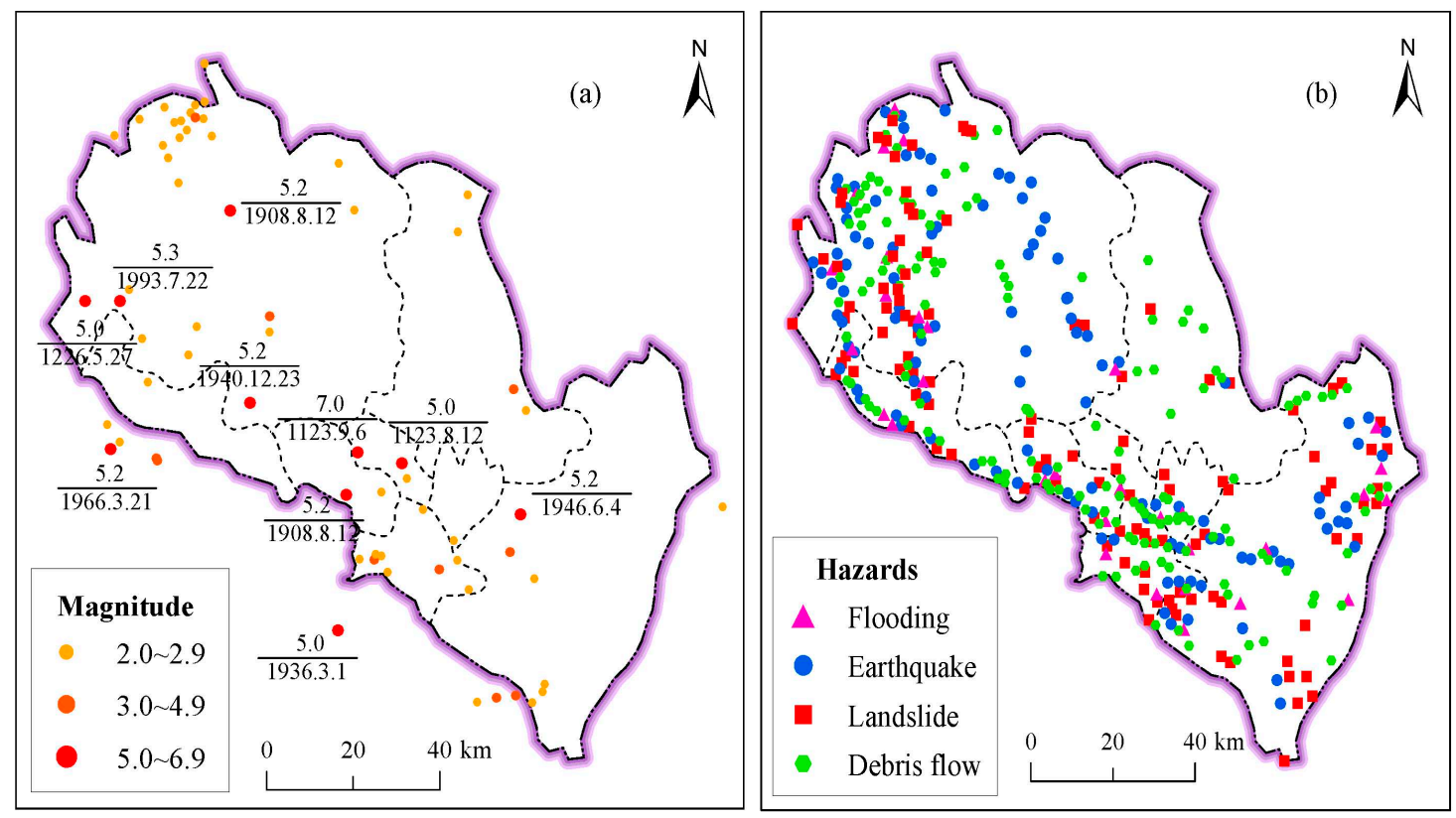

Figure 9. Distribution of (a) historical earthquakes (Data from Yuan [43]); (b) different geohazards collected from 1949 to 2000 (Data from Mei [26] and Chen [55]). 


\section{Results and Analysis}

\subsection{Weights of Assessment Factors}

As mentioned above, assessment of disaster risk using AHP incorporated into GIS is helpful in the assessment of geohazard risk [56-59]. In our assessment model, the hazard index includes annual average rainfall, annual average number of rainy days, geological conditions, earthquake magnitude, and distribution of historic disaster. The exposure index includes elevation, slope, river density, and river proximity. During the establishment of the judgment matrix, the influence of each factor on geohazard risk was investigated by a questionnaire, shown in the Appendix A. The questionnaire was given to more than 20 geohazard experts. Based on the questionnaire responses, the assessment matrixes of hazard index $\left(B_{\text {Hazard }}\right)$ and exposure index $\left(B_{\text {Exposure }}\right)$ were constructed as Equations (11) and (12). These two judgment matrixes are reasonable since the values of $C R$ are less than 0.1 .

$$
\begin{aligned}
B_{\text {Hazard }}= & \left(\begin{array}{ccccc}
1 & \frac{1}{3} & \frac{1}{2} & 2 & \frac{1}{5} \\
3 & 1 & 1 & 2 & \frac{1}{3} \\
2 & 1 & 1 & 2 & \frac{1}{2} \\
\frac{1}{2} & \frac{1}{2} & \frac{1}{2} & 1 & \frac{1}{4} \\
5 & 3 & 2 & 4 & 1
\end{array}\right)(C R=0.0684<0.1) \\
B_{\text {Exposure }} & =\left(\begin{array}{cccc}
1 & \frac{1}{2} & 3 & 5 \\
2 & 1 & 2 & 4 \\
\frac{1}{3} & \frac{1}{2} & 1 & 3 \\
\frac{1}{5} & \frac{1}{4} & \frac{1}{3} & 1
\end{array}\right)(C R=0.06<0.1)
\end{aligned}
$$

By using Equation (6), the weight coefficient of each factor can be calculated. For example, the weight $\left(F_{1}\right)$ for the hazard index can be calculated as follows:

$$
F_{1}=\frac{\sqrt[5]{1 \times \frac{1}{3} \times \frac{1}{2} \times 2 \times \frac{1}{4}}}{\sqrt[5]{1 \times \frac{1}{3} \times \frac{1}{2} \times 2 \times \frac{1}{4}}+\sqrt[5]{3 \times 1 \times 1 \times 2 \times \frac{1}{3}}+\sqrt[5]{2 \times 1 \times 1 \times 2 \times \frac{1}{2}}+\sqrt[5]{\frac{1}{2} \times \frac{1}{2} \times \frac{1}{2} \times 1 \times \frac{1}{4}}+\sqrt[5]{5 \times 3 \times 2 \times 4 \times 1}}
$$

Similarly, the other weights can also be calculated. Table 1 lists the calculated weights of each

\begin{tabular}{|c|c|c|c|c|c|}
\hline $\begin{array}{l}\text { Object } \\
\text { Layer }\end{array}$ & $\begin{array}{l}\text { Index } \\
\text { Layer }\end{array}$ & Weight $\left(R_{\mathrm{i}}\right)$ & Factor Layer & Weight $\left(F_{\mathrm{i}}\right)$ & $\begin{array}{l}\text { Comprehensive } \\
\text { Weight }\left(w_{\mathrm{i}}\right)\end{array}$ \\
\hline \multirow{9}{*}{$\begin{array}{l}\text { Disaster } \\
\text { risk }\end{array}$} & \multirow{5}{*}{ Hazard } & \multirow{5}{*}{0.6} & Annual average rainfall & 0.097 & 0.058 \\
\hline & & & Annual average number of rainy days & 0.192 & 0.115 \\
\hline & & & Geologic condition & 0.192 & 0.115 \\
\hline & & & Earthquake magnitude & 0.084 & 0.051 \\
\hline & & & Historical disaster events & 0.435 & 0.261 \\
\hline & \multirow{4}{*}{ Exposure } & \multirow{4}{*}{0.4} & Topographic elevation & 0.341 & 0.136 \\
\hline & & & Topographical slope & 0.439 & 0.163 \\
\hline & & & River density & 0.175 & 0.071 \\
\hline & & & River proximity & 0.075 & 0.030 \\
\hline
\end{tabular}
assessment factor.

Table 1. Weights of assessment factors calculated by AHP. 


\subsection{Assessment Results}

To obtain the spatial distribution of geohazard risks, the typical factors were mapped and normalized as shown in Figure 10a-f. In these factors, elevation, slope, and river proximities are negative factors: with increased elevation and slope, the risk level will decrease. These negative factors are normalized using Equation (10). The positive factors can be normalized using Equation (9). We suppose that regions where past historical disasters are located have a higher risk than other areas. After normalization, the value of each factor ranged from 0 to 1 and reflected the effects of each disaster risk factor. Figure 10a-e show the spatial distributions of normalized factors. The normalized factors adequately reflect the influence of geohazard risks.
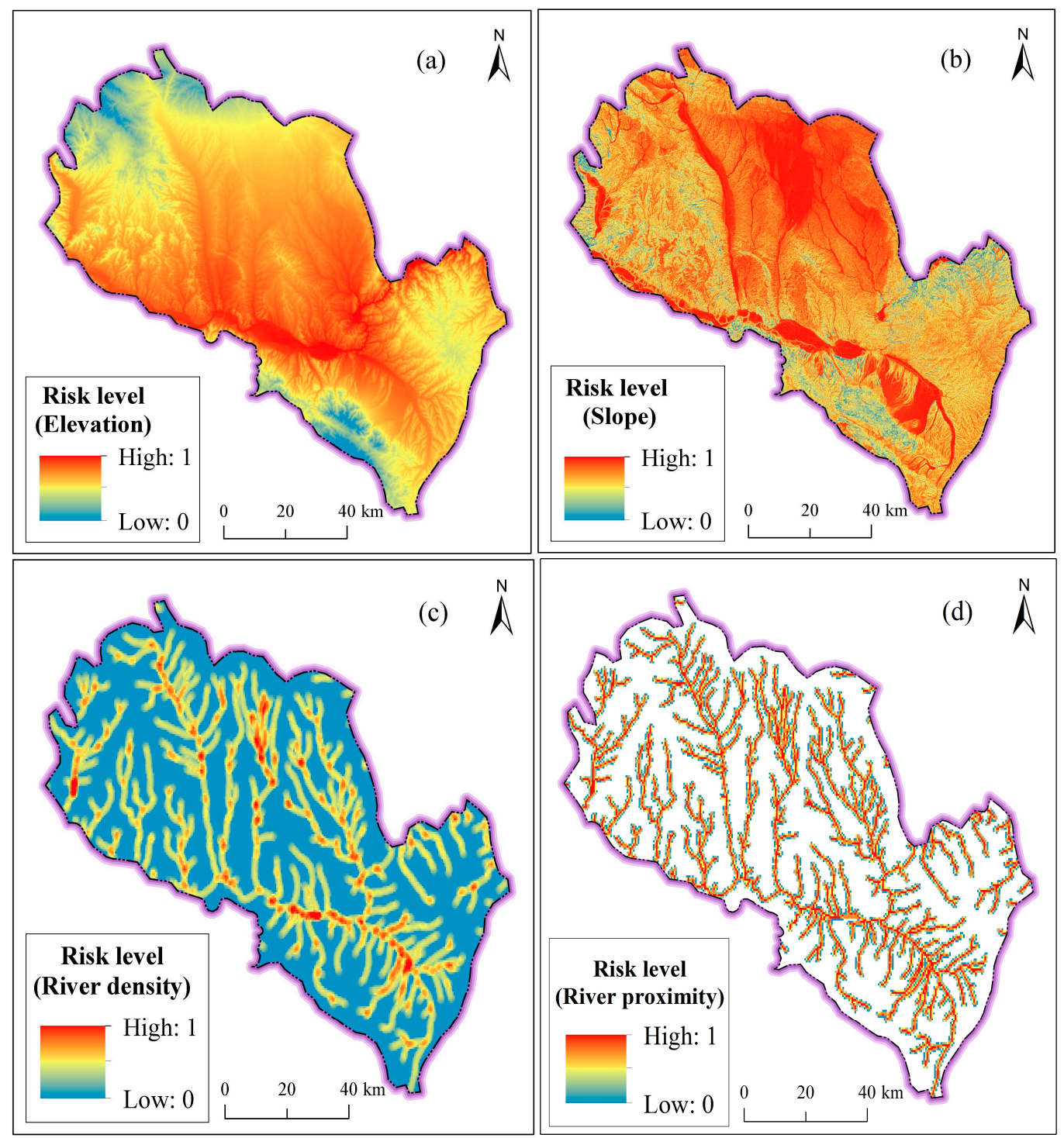

Figure 10. Cont. 


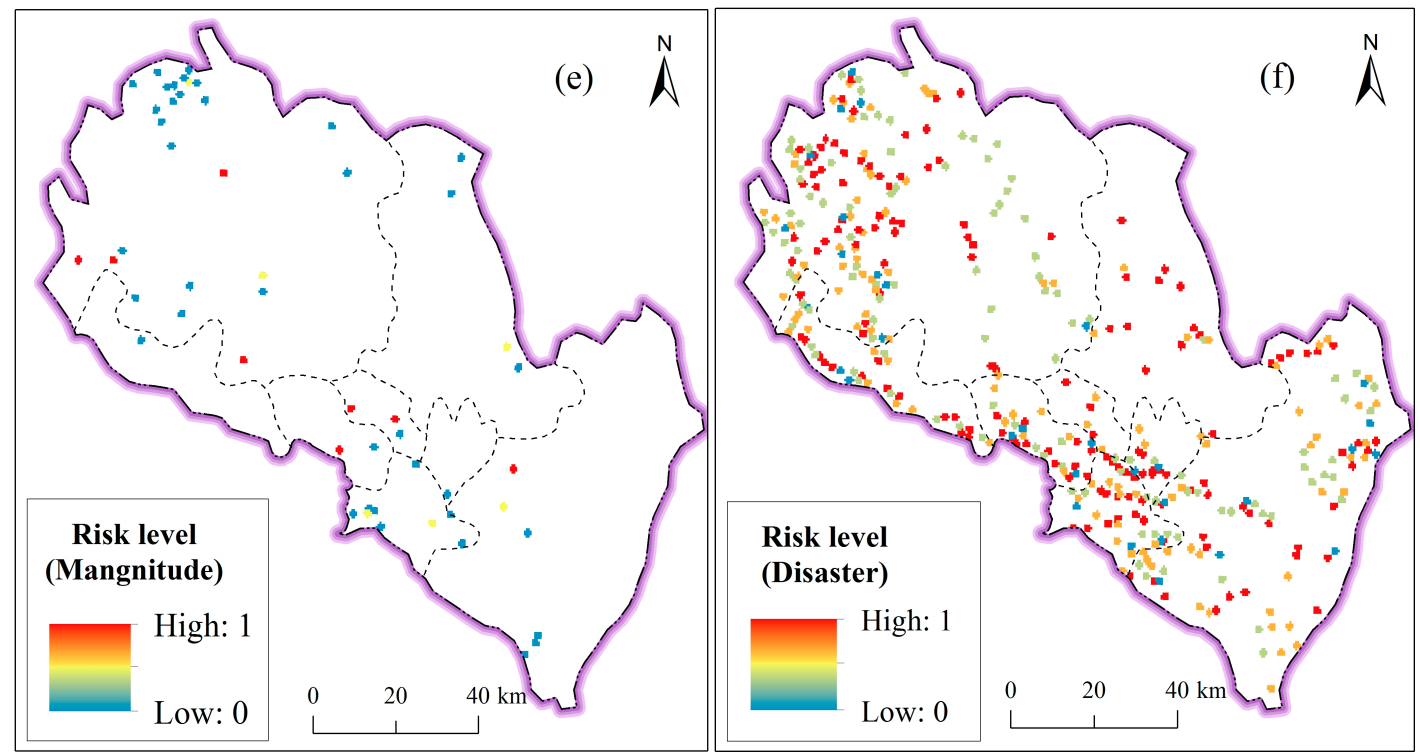

Figure 10. Spatial distribution of normalized factors from assessment result; (a) topographic elevation; (b) topographical slope; (c) river density; (d) river proximity; (e) earthquake magnitude; (f) historical disaster distribution.

Using the normalized grid cell data and the weight coefficient for each factor, a spatial distribution of geohazard risk levels can be obtained. Figure 11 shows the spatial distribution of assessed geohazard risk levels in Lanzhou. As is shown, Lanzhou's urban area has a high risk of geohazards, particularly where there are lower elevations, greater river density, and a history of intensive disaster distribution. Gaolan County, which has a large river density, also has a high risk level. The results reveal that high geohazard risks always appear near rivers. Moreover, historically, geohazards occur at locations classified as having high risk levels. Therefore, long-term historical geohazards are also useful information in assessing risk levels.

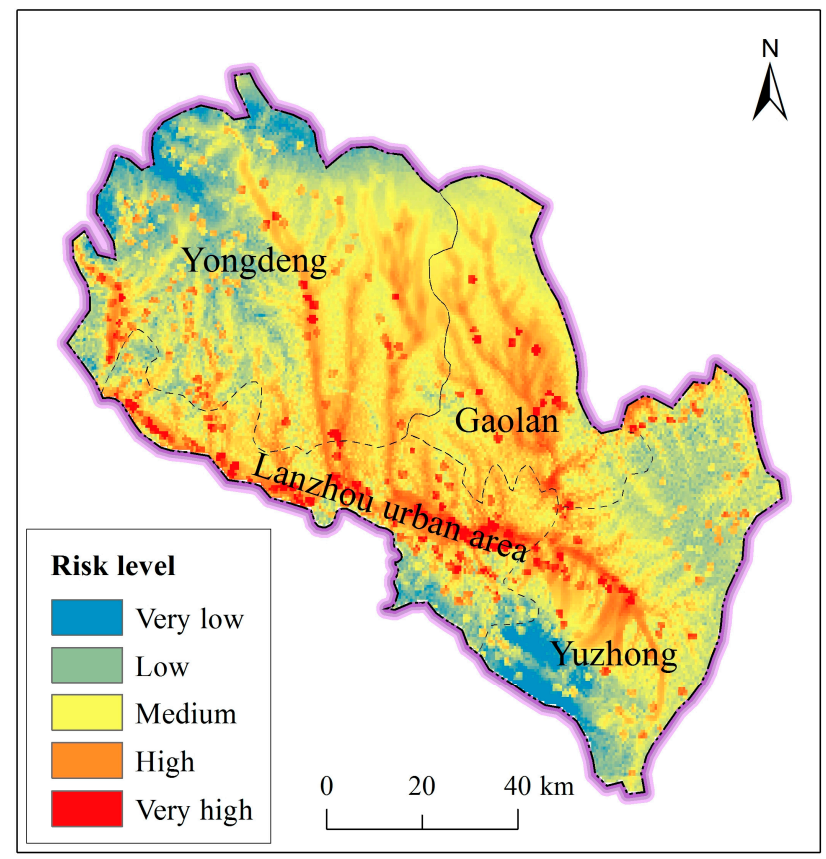

Figure 11. Spatial distribution of geohazard risk levels in Lanzhou City. 
Using the GIS system, the ratio of geohazard risk levels in different districts can be accounted. Table 2 tabulates the ratios of geohazard risk levels in different districts. As is shown, up to $32 \%$ of the total area is at high or very high risk. Over $36 \%$ of the total area is exposed to a medium level of disaster risk. Only $31 \%$ of the area is at low or very low risk. In terms of administrative division, the areas of relative high risk are mainly urban: more than $55 \%$ of the total high-risk area. The second greatest risk is to Gaolan Couty, with $44 \%$ at high or very high risk. Local governments can take measures to prevent geohazards in the regions at high risk based on these assessment results, which it is hoped will be helpful to local governments for sustainable development in urban planning.

Table 2. Ratios of geohazard risk levels in different regions.

\begin{tabular}{cccccc}
\hline \multirow{2}{*}{ Risk Level } & \multicolumn{3}{c}{ Ratio of Risk Level in Different Area (\%) } & \multirow{2}{*}{ Ratio of Whole Region (\%) } \\
\cline { 2 - 4 } & Urban Area & Yuzhong & Gaolan & Yongdeng nn & \multirow{2}{*}{ (\%) } \\
\hline Very low & 3.56 & 9.36 & 0.02 & 9.75 & 24.00 \\
Low & 13.13 & 35.01 & 6.89 & 28.71 & 36.26 \\
Medium & 28.01 & 32.60 & 48.27 & 37.02 & 27.04 \\
High & 38.24 & 18.37 & 40.49 & 22.28 & 5.70 \\
Very high & 17.06 & 4.66 & 4.33 & 2.24 & \\
\hline
\end{tabular}

\subsection{Analysis}

As is shown in Figure 9b, landslides are the most frequent geohazards in Lanzhou City. Thus, the following analyses will focus on landslides, discussing the relationships among topography, geological materials, and landslides.

\subsubsection{Relationship between Topography and Landslides}

The steep loess landforms that pass through the Yellow River result in a large number of geohazards, particularly loess landslides. Topographical characteristics often determine geohazard types. For example, Chongqing City is situated to the southeast of the Sichuan Basin, at the confluence of the Jialing River and Yangtze River, and has a similar topography within the Lanzhou region. Chongqing is surrounded by a dissected mountainous topography, exacerbated by deep weathering of Jurassic sandstone and mudstone. The city experiences at least 500 mostly rock landslides, 89 rock falls, and 185 unstable overhanging rocks per year [60,61].

Hong Kong, on the other hand, is a mountainous island with similar slope topography to Lanzhou. More than $65 \%$ of Hong Kong's land area has a slope gradient greater than $15^{\circ}$, and $30 \%$ has a slope gradient greater than $30^{\circ}$. Hong Kong, too, frequently suffers from catastrophic landslides [61]. The landslides in Hong Kong are the result of natural degradation of steep slopes. During intensive heavy rainstorms, landslides in soils and weathered rock mostly occur on steep slopes, and are generally characterized by rapid motions and fluid-like flows. Investigations have shown that the risk of landslides on the island is low where slopes are gentle and high where they are steep [62-64]. Landslides are prone to occur in steep topography, which may lead to severe landslide damages $[55,65]$. Figure 12 depicts the relationship between the frequency of landslides and slope steepness in Lanzhou City: about $40 \%$ of landslides occur in regions with slopes between $35^{\circ}$ and $50^{\circ}$.

\subsubsection{Relationship between Geological Materials and Landslides}

Material characteristics and hydraulic factors both contribute to the initiation of geohazards. Loess soil is subject to collapse with rainfall infiltration. Soil collapsibility plays a critical role in slope stability [55,65]. Slopes with loess soils lose significant stability when encountering concentrated rainfall, which eventually leads to landslides. Figure 13 shows the number of landslides in Lanzhou, by type with their attributed triggers, from 1990 to 2009 [55]. As is shown, most landslides in Lanzhou are loess landslides triggered by rainfall. Moreover, quaternary loese deposits at steep topographies 
develop debris flow during rainstorms. Debris flow can be initiated from landslides and saturated slope failure, causing rapid sediment entrainment. Geological materials have significant effects on landslide velocity [66-68]. Loess and erosion settlements easily create the homogeneous fluids of debris flow, which can travel with high flow velocity, impact force, and long runout in Lanzhou City.

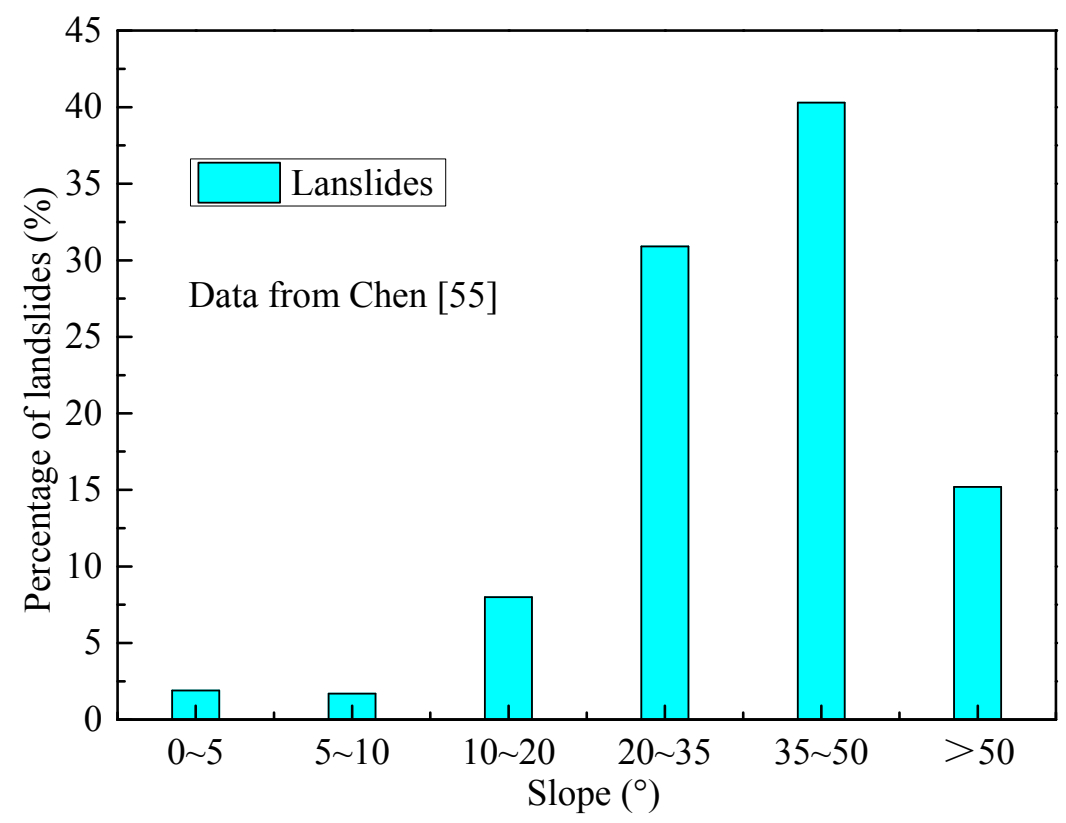

Figure 12. Relationship between the percentage of landslides and slope in Lanzhou City.

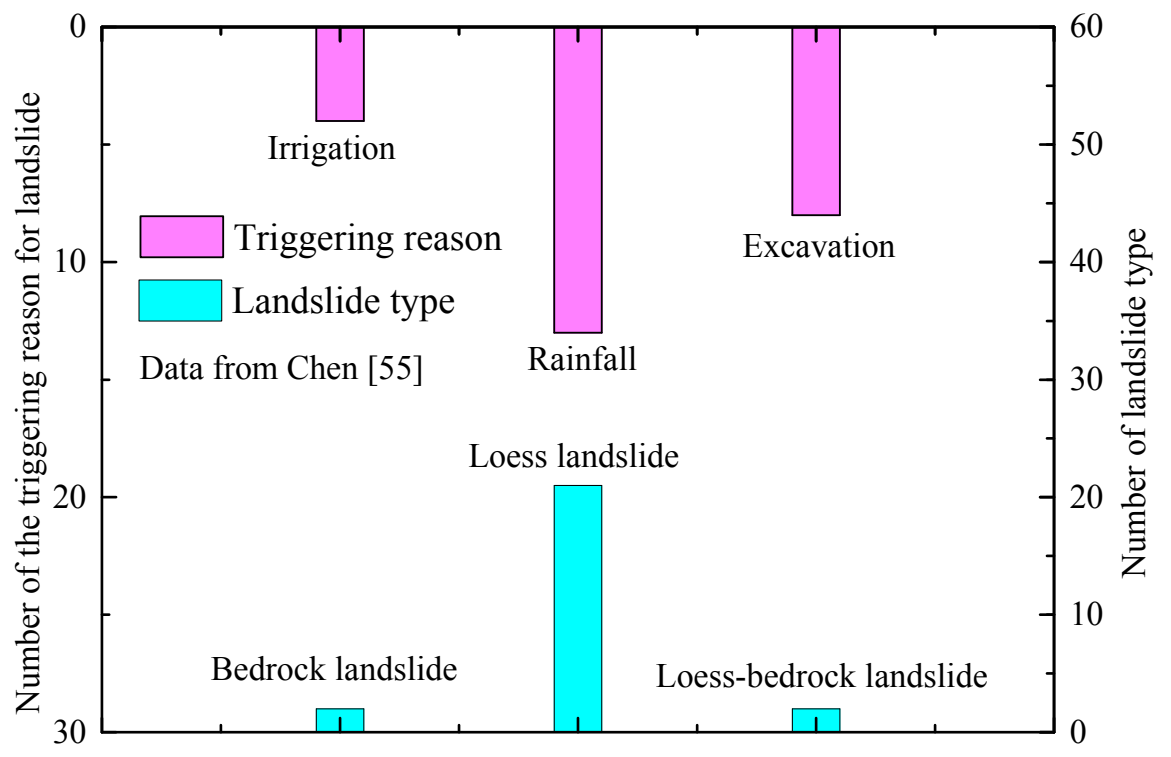

Figure 13. Numbers of landslide types and triggering factors in Lanzhou City from 1990 to 2009.

\section{Strategic Decision Making and Technical Countermeasures}

\subsection{Strategic Decision Making Suggestions}

Strategic decision making regarding geohazard mitigation should be conducted based on the comprehensive technical assessment of geohazard risk. The geographical position and environmental conditions of Lanzhou require specific strategies to prevent and mitigate geohazards. Strategies adopted by local residents and government should follow the procedures proposed by the United Nations 
Office for Disaster Risk Reduction (UNISDR) [69]: governments should organize professionals and researchers to develop a comprehensive unified plan; communities should improve popular awareness of environmental protection and prohibit human activities that may trigger geological disasters; and local governments or communities should carry out comprehensive surveys and establish instructive prevention plans against geohazards.

\subsection{Countermeasures for Landslide-Accompanied Debris Flow}

Landslides accompanied by debris flows have a significant relationship to rainfall events [70,71]. Along with the aforementioned strategic decision making, it is also important to adopt technical countermeasures to prevent landslides. To avoid deterioration, regular slope maintenance is essential. Effective strategies to guarantee slope stability against landslides are: revising slopes to reduce the inclination of the slope from steep to gentle; constructing retaining walls (for example, reinforced earth or concrete walls); providing anchors (for example, soils and pre-stressed anchors) to reduce slop failures; providing effective drainage systems; and compacting loose fill slopes [72,73]. The rest of this section discusses detailed countermeasures to mitigate landslides accompanied debris flows, since these geohazards are common in Lanzhou City.

Flexible barriers are common countermeasures to restrain debris flow and protect from rock fall hazards [74-76]. These barriers are made of a light structure in which a certain number of posts keep in position a steel mesh and a series of steel cables. The mesh stops the moving blocks and transfers all the forces to the anchors in the ground. Figure 14a,b show this type of flexible barrier: Figure 14a shows protection against rock hazard and Figure 14b shows the application of flexible barriers for debris flows in Zhouqu City, Gansu Province, which suffered a strong debris flow in 2014 [76]. As mentioned before, Lanzhou city is surrounded by several mountains (Gaolan Mountain, Xinlong Mountain, and Baita Mountain: see Figure 5). Structural countermeasures such as rigid and flexible barriers are commonly installed in mountainous regions to intercept mass-wasting processes, and are recommended to prevent debris flows in Lanzhou. In addition, to mitigate the damage of debris flow, local governments that monitor debris flow warning systems should adhere to operating standards in the monitoring process.

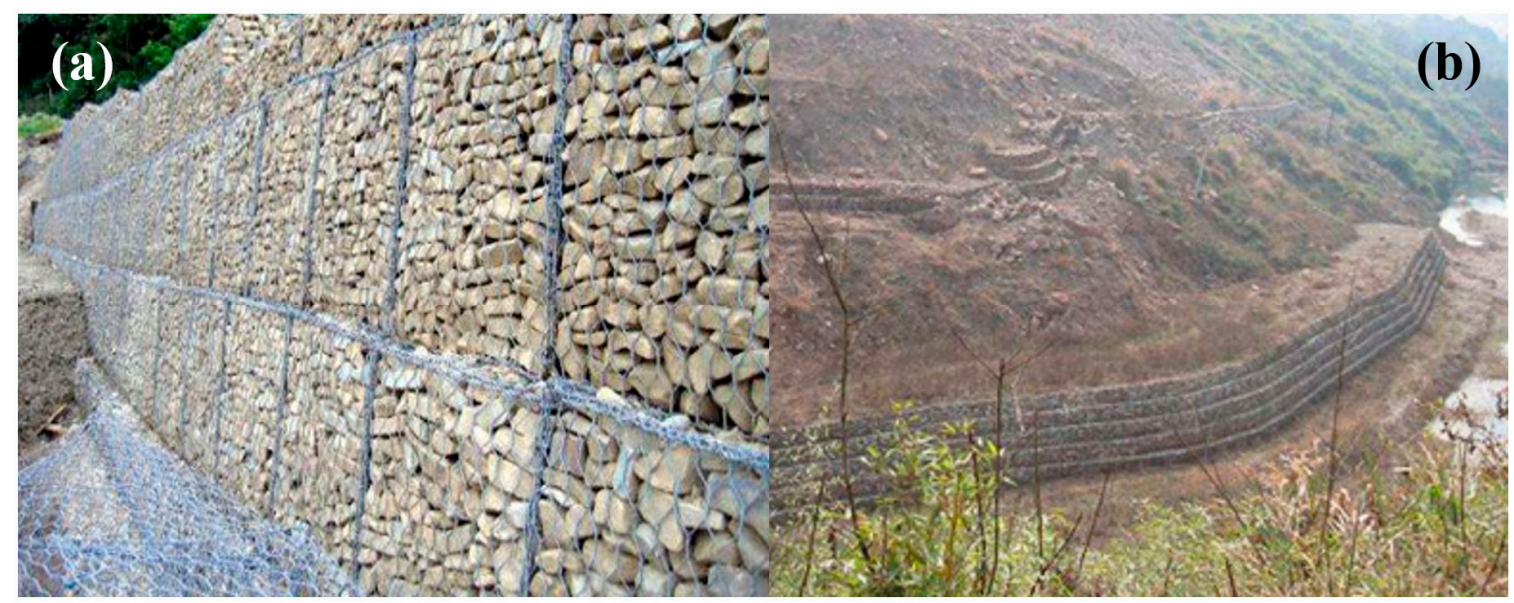

Figure 14. Flexible barriers: (a) net barriers against rock fall risk after construction; (b) flexible barrier for debris flow in Zhouqu City, Gansu Province.

\subsection{Early Monitoring System for Earthquake and Flood}

Earthquakes can cause frequent rock falls and landslides in mountain ridges and watershed slopes. Landslide masses are scattered on the upper middle parts of the mountains in Lanzhou. When subjected to intense rainfall, loose deposits accumulate along gullies, forming devastating 
high-velocity debris flows: a typical earthquake-landslide-debris flow disaster chain [77]. Earthquakes and floods are the inducing factors for landslides and debris flows. Therefore, to mitigate geohazard ripple effects, it is important to monitor earthquakes and rainstorms. The China Earthquake Administration has authorized the China Earthquake Background Field Exploration Project and the National Earthquake Social Service Project, and constructed two demonstrative earthquake early warning systems in Beijing and Lanzhou [44]. The construction and operation of these early warning systems have provided excellent results for the development of earthquake early warning in China.

Since Lanzhou's rainfall is concentrated from July to September, potential flooding disaster may develop in these months. Due to lower rainfall in Lanzhou City, flood risk there is relatively lower than elsewhere in the province, but rainfall can induce other geohazards (for example, landslides accompanied with debris flows). Therefore, it is also necessary to monitor the rainfall in Lanzhou.

\section{Conclusions}

This work has investigated geohazards affecting Lanzhou. Local landforms, topography, geology, and hydrogeology were analyzed and risk assessment was applied to evaluate geohazard risk levels in different regions. Based on our investigations and risk assessment, countermeasures for prevention of geohazards have been discussed. The flowing conclusions can be drawn:

1. The geohazards investigation shows that intensive seasonal short-duration rainstorm and special loess landforms with many vertical fissures contribute to frequent landslides, which are often accompanied by debris flows. Faults and strong neotectonic movements provide geological conditions which are conducive to earthquakes. The disaster chain of earthquake-landslide-debris flow is common in Lanzhou City.

2. Geohazard risk assessment results show that $32 \%$ of the total area is at high or very high risk. About $55 \%$ of the urban area and $44 \%$ of Gaolan county are at high or very high risk. During the monitoring process, local governments should pay particular attention to these high-risk regions.

3. Appropriate countermeasures include the establishment of relationships between geohazards (for example, landslides accompanied with debris flows), topography, and geological materials. Regular slope maintenance is an effective way to further mitigate landslide events, while the installation of flexible barriers is useful to restrain debris flows.

Acknowledgments: The work described herein was funded by the National Nature Science Foundation of China (NSFC) (Grant No. 41672259). This financial support is gratefully acknowledged.

Author Contributions: This paper represents a result of collaborative teamwork. Jack Shuilong Shen developed the idea of the manuscript, checked the calculation results, and revised the manuscript; Hai-Min Lyu did AHP analysis and drafted the manuscript; and Arul Arulrajah provided constructive suggestions both for technical and manuscript preparation. The three authors contributed equally to this work.

Conflicts of Interest: The authors declare no conflict of interest.

\section{Appendix A}

In this questionnaire, the influence of each factor on geohazards risk was defined along a range from "equal" to "extreme", numbered 1-9. Table A1 shows the questionnaire. 


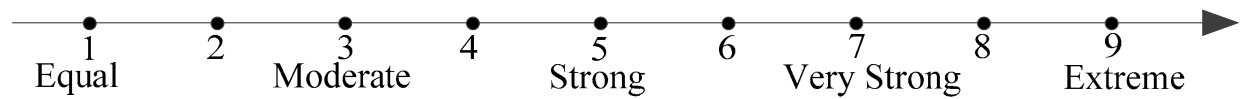

Table A1. Questionnaire for geohazards risk assessment.

\begin{tabular}{|c|c|c|c|c|c|c|c|c|c|}
\hline \multirow{2}{*}{ Factor } & \multicolumn{9}{|c|}{ Influence Degree to Geohazards Risk } \\
\hline & 1 & 2 & 3 & 4 & 5 & 6 & 7 & 8 & 9 \\
\hline \multicolumn{10}{|l|}{ Average annual rainfall } \\
\hline \multicolumn{10}{|l|}{ Average annual rainy day } \\
\hline \multicolumn{10}{|l|}{ Geological environment } \\
\hline \multicolumn{10}{|l|}{ Earthquake magnitude } \\
\hline \multicolumn{10}{|l|}{ Historical disaster } \\
\hline \multicolumn{10}{|l|}{ Topographical slope } \\
\hline \multicolumn{10}{|l|}{ Topographical elevation } \\
\hline \multicolumn{10}{|l|}{ River density } \\
\hline River proximity & & & & & & & & & \\
\hline
\end{tabular}

\section{References}

1. Lyu, H.M.; Wang, G.F.; Shen, J.S.; Lu, L.H.; Wang, G.Q. Analysis and GIS mapping of flooding hazards on 10 May, 2016, Guangzhou, China. Water 2016, 8, 447. [CrossRef]

2. Lyu, H.M.; Wang, G.F.; Cheng, W.C.; Shen, S.L. Tornado hazards on June 23 in Jiangsu Province, China: Preliminary investigation and analysis. Nat. Hazards 2017, 85, 597-604. [CrossRef]

3. Shi, H.; Chen, J.; Wang, K.; Niu, J. A new method and a new index for identifying socioeconomic drought events under climate change: A case study of the East River basin in China. Sci. Total Environ. 2018, 616, 363-375. [CrossRef] [PubMed]

4. Li, Y.; Ma, C.; Wang, Y. Landslides and debris flows caused by an extreme rainstorm on 21 July 2012 in mountains near Beijing, China. Bull. Eng. Geol. Environ. 2017, 1-16. [CrossRef]

5. Yang, L.; Scheffran, J.; Qin, H.; You, Q. Climate-related flood risks and urban responses in the Pearl River Delta, China. Reg. Environ. Chang. 2015, 15, 379-391. [CrossRef]

6. Liu, X. Hazard assessment of debris flows in Lanzhou City. Northwest Geol. 2016, 49, 257-262.

7. Jeong, S.; Kim, Y.; Lee, K.; Kim, J. Advances in debris-flow hazard assessment in mountainous area. Jpn. Geotech. Soc. Spec. Publ. 2016, 2, 1137-1142. [CrossRef]

8. Iverson, R.M. Landslide triggering by rain infiltration. Water Resour. Res. 2000, 36, 1897-1910. [CrossRef]

9. Fan, X.; Xu, Q.; Scaringi, G.; Li, S.; Peng, D. A chemo-mechanical insight into the failure mechanism of frequently occurred landslides in the Loess Plateau, Gansu Province, China. Eng. Geol. 2017, 228, 337-345. [CrossRef]

10. Bai, S.; Xu, Q.; Wang, J.; Zhou, P. Pre-conditioning factors and susceptibility assessments of Wenchuan earthquake landslide at the Zhouqu segment of Bailongjiang basin, China. J. Geol. Soc. India 2013, 82, 575-582. [CrossRef]

11. Bai, S.; Wang, J.; Zhang, Z.; Cheng, C. Combined landslide susceptibility mapping after Wenchuan earthquake at the Zhouqu segment in the Bailongjiang Basin, China. Catena 2012, 99, 18-25. [CrossRef]

12. Lyu, H.M.; Sun, W.J.; Shen, S.L.; Arulrajah, A. Flood risk assessment in metro systems of mega-cities using a GIS-based modeling approach. Sci. Total Environ. 2018. [CrossRef]

13. Shen, S.L.; Wang, Z.F.; Yang, J.; Ho, E.C. Generalized approach for prediction of jet grout column diameter. J. Geotech. Geoenviron. Eng. 2013, 139, 2060-2069. [CrossRef]

14. Shen, S.L.; Xu, Y.S. Numerical evaluation of land subsidence induced by groundwater pumping in Shanghai. Can. Geotech. J. 2011, 48, 1378-1392. [CrossRef]

15. Shen, S.L.; Wu, H.N.; Cui, Y.J.; Yin, Z.Y. Long-term settlement behavior of the metro tunnel in the soft deposits of Shanghai. Tunn. Undergr. Space Technol. 2014, 40, 309-323. [CrossRef]

16. Shen, S.L.; Wang, Z.F.; Cheng, W.C. Estimation of lateral displacement induced by jet grouting in clayey soils. Geotechnique 2017, 67, 621-630. [CrossRef]

17. Wu, H.N.; Shen, S.L.; Liao, S.M.; Yin, Z.Y. Longitudinal structural modelling of shield tunnels considering shearing dislocation between segmental rings. Tunn. Undergr. Space Technol. 2015, 50, 317-323. [CrossRef] 
18. Wu, Y.X.; Shen, S.L.; Yuan, D.J. Characteristics of dewatering induced drawdown curve under barrier effect of retaining wall in aquifer. J. Hydrol. 2016, 539, 554-566. [CrossRef]

19. Yin, Z.Y.; Jin, Y.F.; Shen, S.L.; Hicher, P.Y. Optimization techniques for identifying soil parameters in geotechnical engineering: comparative study and enhancement. Int. J. Numer. Anal. Methods Geomech. 2018, 42, 70-94. [CrossRef]

20. Xu, Y.S.; Shen, S.L.; Ren, D.J.; Wu, H.N. Analysis of factors in land subsidence in Shanghai: A view based on a strategic environmental assessment. Sustainability 2016, 8, 573. [CrossRef]

21. Cheng, W.C.; Ni, J.C.; Shen, S.L. Experimental and analytical modeling of shield segment under cyclic loading. Int. J. Geomech. 2016, 17, 04016146. [CrossRef]

22. Du, Y.J.; Wei, M.L.; Reddy, K.R.; Liu, Z.P.; Jin, F. Effect of acid rain pH on leaching behavior of cement stabilized lead-contaminated soil. J. Hazard. Mater. 2014, 271, 131-140. [CrossRef] [PubMed]

23. Huang, Y.; Yashima, A.; Sawada, K.; Zhang, F. Numerical assessment of the seismic response of an earth embankment on liquefiable soils. Bull. Eng. Geol. Environ. 2008, 67, 31. [CrossRef]

24. Zhang, Y.; Lu, W.X.; Yang, Q.C. The impacts of mining exploitation on the environment in the Changchun-Jilin-Tumen economic area, Northeast China. Nat. Hazards 2015, 76, 1019-1038. [CrossRef]

25. Nisio, S.; Caramanna, G.; Ciotoli, G. Sinkholes in Italy: First results on the inventory and analysis. Geol. Soc. Spec. Publ. 2007, 279, 23-45. [CrossRef]

26. Mei, H.; Zhang, J.X. Types and distribution of geological hazards in Lanzhou city. South-to-North Water Transf. Water Sci. Technol. 2012, 8, 53-58. (In Chinese)

27. Zhang, W.; Shi, Z.; Chen, G.; Liu, Y.; Niu, J.; Ming, Q.; Su, H. Geochemical characteristics and environmental significance of Talede loess-paleosol sequences of Ili Basin in Central Asia. Environ. Earth Sci. 2013, 70, 2191-2202. [CrossRef]

28. Borjigidai, A.; Xi, Y.; Duan, F. Assessment of characteristics and impact of earthquake disasters in the minority regions of southwest China. J. Nat. Disasters 2014, 23, 84-89.

29. Black, A.R.; Burns, J.C. Re-assessing the flood risk in Scotland. Sci. Total Environ. 2002, 294, 169-184. [CrossRef]

30. Willems, P. Revision of urban drainage design rules after assessment of climate change impacts on precipitation extremes at Uccle, Belgium. J. Hydrol. 2013, 496, 166-177. [CrossRef]

31. Li, Z.; Ma, Z.; van der Kuijp, T.J.; Yuan, Z.; Huang, L. A review of soil heavy metal pollution from mines in China: pollution and health risk assessment. Sci. Total Environ. 2014, 468, 843-853. [CrossRef] [PubMed]

32. Jiang, W.; Deng, L.; Chen, L.; Wu, J.; Li, J. Risk assessment and validation of flood disaster based on fuzzy mathematics. Prog. Nat. Sci. 2009, 19, 1419-1425. [CrossRef]

33. Kazakis, N.; Kougias, I.; Patsialis, T. Assessment of flood hazard areas at a regional scale using an index-based approach and analytical hierarchy process: Application in Rhodope-Evros region, Greece. Sci. Total Environ. 2015, 538, 555-563. [CrossRef] [PubMed]

34. Tanavud, C.; Yongchalermchai, C.; Bennui, A.; Densreeserekul, O. Assessment of flood risk in Hat Yai municipality, Southern Thailand, using GIS. J. Nat. Disaster Sci. 2004, 26, 1-14. [CrossRef]

35. Meesuk, V.; Vojinovic, Z.; Mynett, A.E.; Abdullah, A.F. Urban flood modelling combining top-view LiDAR data with ground-view SfM observations. Adv. Water Resour. 2015, 75, 105-117. [CrossRef]

36. Yi, C.S.; Lee, J.H.; Shim, M.P. GIS-based distributed technique for assessing economic loss from flood damage: Pre-feasibility study for the Anyang Stream Basin in Korea. Nat. Hazards 2010, 55, 251-272. [CrossRef]

37. Ayalew, L.; Yamagishi, H.; Marui, H.; Kanno, T. Landslides in Sado Island of Japan: Part II. GIS-based susceptibility mapping with comparisons of results from two methods and verifications. Eng. Geol. 2005, 81, 432-445. [CrossRef]

38. Arisido, M.W.; Gaetan, C.; Zanchettin, D.; Rubino, A.A. Bayesian hierarchical approach for spatial analysis of climate model bias in multi-model ensembles. Stoch. Environ. Res. Risk Assess. 2017, 31, 2645-2657. [CrossRef]

39. Zhang, J.; Zhang, L.M.; Tang, W.H. Bayesian framework for characterizing geotechnical model uncertainty. J. Geotech. Geoenviron. Eng. 2009, 135, 932-940. [CrossRef]

40. Samela, C.; Troy, T.J.; Manfreda, S. Geomorphic classifiers for flood-prone areas delineation for data-scarce environments. Adv. Water Resour. 2017, 102, 13-28. [CrossRef]

41. Science Museums of China (SMC). Loess Plateau Loess Distribution and Thickness Map. Available online: http:/ / www.kepu.net.cn/gb / practicecenter/201001_01_htgy/xingcheng/huangtu.html (accessed on 12 December 2017). 
42. Su, L.H.; Yao, Z.H.; Huang, X.F.; Li, N.; Qu, Y.H. Water migration regularity of self-weight collapsible loess ground. Chin. J. Rock Mech. Eng. 2016, 35, 4328-4336. (In Chinese)

43. Yuan, D.; Wang, L.; He, W.; Lu, B.; Ge, W.; Liu, X.; Liang, M.; Zheng, W. New progress of seismic active fault prospecting in Lanzhou city. Seismol. Geol. 2008, 30, 236-249. (In Chinese)

44. Tian, X.; Zeng, W.; Pan, Z.; Zhang, W.; Yuan, J.; Zhang, X. Status quo of Lanzhou earthquake early warning system and analysis of its key technical indicators. J. Phys Conf. Ser. 2017, 910, 012072. [CrossRef]

45. Cruden, D.M. A simple definition of a landslide. Bull. Eng. Geol. Environ. 1991, 43, 27-29. [CrossRef]

46. Sun, P.; Peng, J.; Chen, L.; Lu, Q.; Igwe, O. An experimental study of the mechanical characteristics of fractured loess in western China. Bull. Eng. Geol. Environ. 2016, 75, 1639-1647. [CrossRef]

47. DeVore, J.R.; Sawyer, D.E. Shear strength of siliciclastic sediments from passive and active margins (0-100 m below seafloor): Insights into seismic strengthening. In Submarine Mass Movements and Their Consequences; Springer: Berlin, Germany, 2016; pp. 173-180.

48. Rovins, J.E.; Wilson, T.M.; Hayes, J.; Jensen, S.J.; Dohaney, J.; Mitchell, J.; Johnston, D.M.; Davies, A. Risk Assessment Handbook; GNS Science Miscellaneous Series; Massey University: Palmerston North, New Zealand, 2015.

49. Ghesquiere, F.; Kellett, J.; Campbell, J.; Kc, S.; Reid, R. The Sendai Report: Managing Disaster Risks for a Resilient Future; The World Bank: Washington, DC, USA, 2012.

50. Liu, R.; Chen, Y.; Wu, J.; Gao, L.; Barrett, D.; Xu, T.; Yu, J. Assessing spatial likelihood of flooding hazard using naïve Bayes and GIS: A case study in Bowen Basin, Australia. Stoch. Environ. Res. Risk Assess. 2016, 30, 1575-1590. [CrossRef]

51. Liu, R.; Chen, Y.; Wu, J.; Gao, L.; Barrett, D.; Xu, T.; Yu, J. Integrating Entropy-Based Naïve Bayes and GIS for Spatial Evaluation of Flood Hazard. Risk Anal. 2017, 37, 756-773. [CrossRef] [PubMed]

52. Saaty, T.L. A scaling method for priorities in hierarchical structures. J. Math. Psychol. 1977, 15, $234-281$. [CrossRef]

53. Saaty, T.L. How to make a decision: The analytic hierarchy process. Eur. J. Oper. Res. 1990, 48, 9-26. [CrossRef]

54. Saaty, T.L. Decision making with the analytic hierarchy process. Int. J. Serv. Sci. 2008, 1, 83-98. [CrossRef]

55. Chen, G.; Feng, X.D.; Gao, L. Comparison with characteristics of landslide and other geological hazards in Lanzhou. Sci. Technol. Vis. 2012, 5, 213-215. (In Chinese)

56. Xiao, Y.; Yi, S.; Tang, Z. Integrated flood hazard assessment based on spatial ordered weighted averaging method considering spatial heterogeneity of risk preference. Sci. Total Environ. 2017, 599, 1034. [CrossRef] [PubMed]

57. Luu, C.; Von Meding, J.; Kanjanabootra, S. Assessing flood hazard using flood marks and analytic hierarchy process approach: A case study for the 2013 flood event in Quang Nam, Vietnam. Nat. Hazards 2017, 30, 1031-1050. [CrossRef]

58. Sun, D.C.; Huang, J.; Wang, H.M.; Wang, Z.Q.; Wang, W.Q. Risk assessment of urban flood disaster in Jingdezhen City based on analytic hierarchy process and geographic information system. In IOP Conference Series: Earth and Environmental Science; IOP Publishing: Bristol, UK, 2017; Volume 82, p. 012075.

59. Correia, F.N.; Rego, F.C.; Saraiva, M.D.G.; Ramos, I. Coupling GIS with hydrologic and hydraulic flood modelling. Water Resour. Manag. 1998, 12, 229-249. [CrossRef]

60. Carey, P.J.; Schmid-Mcgibbon, G.; Liu, Z.X.; Li, T.M. Geohazards in the Chongqing district of China. In Urban Ground Engineering, Proceeding of the International Conference Organized by the Institution of Civil Engineers, Hong Kong, China, 11-12 November 1999; Institution of Civil Engineers: London, UK, 1999; pp. 320-331.

61. Chen, K.L.; Wu, H.N.; Cheng, W.C.; Zhang, Z.; Chen, J. Geological characteristics of strata in Chongqing, China, and mitigation of the environmental impacts of tunneling-induced geo-hazards. Environ. Earth Sci. 2017, 76, 10. [CrossRef]

62. Chen, H.; Lee, C.F. Geohazards of slope mass movement and its prevention in Hong Kong. Eng. Geol. 2004, 76, 3-25. [CrossRef]

63. Kim, M.S.; Onda, Y.; Uchida, T.; Kim, J.K.; Song, Y.S. Effect of seepage on shallow landslides in consideration of changes in topography: Case study including an experimental sandy slope with artificial rainfall. Catena 2018, 161, 50-62. [CrossRef]

64. Bandara, S.; Ohtsuka, S. Spatial distribution of landslides induced by the 2004 Mid-Niigata prefecture earthquake, Japan. Landslides 2017, 14, 1877-1886. [CrossRef] 
65. Shi, J.S.; Shi, L.; Wu, S.R.; Wang, T. Difficulties and countermeasures in the practice of landslide risk assessment. Geol. Bull. China 2009, 28, 1020-1030.

66. Yao, Y.P.; Zhou, A.N. Non-isothermal unified hardening model: A thermo-elastoplastic model for clays. Geotechnique 2013, 63, 1328-1345. [CrossRef]

67. Yao, Y.P.; Hou, W.; Zhou, A.N. UH model: three-dimensional unified hardening model for overconsolidated clays. Geotechnique 2009, 59, 451-469. [CrossRef]

68. Yao, Y.P.; Sun, D.A.; Matsuoka, H. A unified constitutive model for both clay and sand with hardening parameter independent on stress path. Comput. Geotech. 2008, 35, 210-222. [CrossRef]

69. Nkwunonwo, U.C.; Whitworth, M.; Baily, B. A review and critical analysis of the efforts towards urban flood risk management in the Lagos region of Nigeria. Nat. Hazards Earth Syst. Sci. 2016, 16, 349-369. [CrossRef]

70. Guzzetti, F.; Peruccacci, S.; Rossi, M.; Stark, C.P. The rainfall intensity-duration control of shallow landslides and debris flows: An update. Landslides 2008, 5, 3-17. [CrossRef]

71. Finlay, P.J.; Fell, R.; Maguire, P.K. The relationship between the probability of landslide occurrence and rainfall. Can. Geotech. J. 1997, 34, 811-824. [CrossRef]

72. Yoshimatsu, H.; Abe, S. A review of landslide hazards in Japan and assessment of their susceptibility using an analytical hierarchic process (AHP) method. Landslides 2006, 3, 149-158. [CrossRef]

73. Zhang, X.H.; Lei, C.F.; Li, H.F. Study on natural disaster prevention countermeasures for Western Valley City from the perspective of city planning: A case of Lanzhou city. Appl. Mech. Mater. 2013, 409, 827-832. [CrossRef]

74. Vagnon, F.; Ferrero, A.M.; Umili, G.; Segalini, A. A factor strength approach for the design of rock fall and debris flow barriers. Geotech. Geol. Eng. 2017, 35, 2663-2675. [CrossRef]

75. Ng, C.W.W.; Song, D.; Choi, C.E.; Liu, L.H.D.; Kwan, J.S.H.; Koo, R.C.H.; Pun, W.K. Impact mechanisms of granular and viscous flows on rigid and flexible barriers. Can. Geotech. J. 2016, 54, 188-206. [CrossRef]

76. Shu, H.P.; Wang, G.; Zhang, P.; Ma, J.Z. Assessment of the Risk of Debris Flows in Zhouqu County, South Gansu Province, China. Adv. Mater. Res. 2014, 955, 1617-1621. [CrossRef]

77. Zhang, Y.S.; Cheng, Y.L.; Yao, X.; Wang, J.; Wu, S.R.; Wang, M. The evolution process of Wenchuan earthquake-landslide-debris flow geohazard chain. Geol. Bull. China 2013, 32, 1900-1910. 